УДК $341.24(4: 520)$

DOI: $10.18384 / 2310-6794-2021-1-15-24$

\title{
TOPICAL ISSUES OF LEGAL REGULATION OF INTERNATIONAL AGREEMENTS ON THE EXAMPLE OF EAST AND WEST (THEORETICAL AND LEGAL RESEARCH)
}

\author{
Pierre-Yves Monjal \\ University of Tours \\ 60, rue du Plat D'Etain, Tours, 37020, France
}

\begin{abstract}
Aim. Analyze the ongoing changes in the process of establishing relations between the European Union and Japan for a better implementation of the Economic Partnership Agreement.

Methodology. An analysis of the current legislation of the European Union and Japan was carried out, as well as a retrospective review.

Results. The article identifies the main problems of legal regulation of the process of establishing economic partnership between the European Union and Japan and ways to improve and optimize them.

Research implications. This work contains an in-depth analysis of a significant number of regulations of the European Union and Japan that determine their economic relations at the international level. The main ways of eliminating contradictions between the existing normative acts were highlighted.
\end{abstract}

Keywords: Economic partnership, European Union, Japan, international cooperation.

\section{АКТУАЛЬНЫЕ ВОПРОСЫ ПРАВОВОГО РЕГУЛИРОВАНИЯ МЕЖДУНАРОДНЫХ СОГЛАШЕНИЙ НА ПРИМЕРЕ ВОСТОКА И ЗАПАДА (ТЕОРЕТИКО-ПРАВОВОЕ ИССЛЕДОВАНИЕ)}

\section{Монжал П. -И.}

Турский университет

37020, г. Тур, ул. дю Пла д'Этен, д. 60, Франция

\begin{abstract}
Аннотация
Цель. Анализ изменений, происходящих в процессе установления отношений между Европейским Союзом и Японией, направленных на более качественную реализацию соглашения об экономическом партнёрстве.
\end{abstract}

Процедура и методы. Проведён анализ современного законодательства Евросоюза и Японии, а также сделан его ретроспективный обзор.

Результаты. В статье обозначены основные проблемы правового регулирования процесса установления экономического сотрудничества между Европейским Союзом и Японией, а также способы их оптимизации.

Теоретическая и/или практическая значимость. В статье тщательно проанализирован значительный объём нормативных документов Евросоюза и Японии, определяющих их экономические отношения на международном уровне. Выделены основные способы преодоления противоречий между существующими нормативными актами.

Ключевые слова: экономическое сотрудничество, Европейский Союз, Япония, международное сотрудничество

(c) CC BY Pierre-Yves Monjal, 2021. 


\section{Introduction}

The Economic Partnership Agreement (EPA) between Japan and European Union (EU) raises a number of questions which, from the point of view of the law of the EU's external agreements or the general problem of its external competences, illustrate this new bilateral trend which the EU now promote in its trade policy. What is at issue here, as we know, is the question - not to say the concept of new generation agreements, which deserve special attention and of which the EPA is a perfect example. In any event, the links now established between the European Union and Japan will have the virtue, beyond the purely commercial aspects, of bringing our two «worlds» closer together, which undoubtedly have a great deal in common and which deserve to be deepened. Thus, we will affirm or recall, through a historical mirror game, that if Nintendo owes its worldwide success to two Europeans (I), it is because the mother of Europe is undoubtedly Japanese (II).

\section{Nintendo owes its success to two Europeans}

In the closing statement on 6 July 2018 in Brussels, Cécilia Malmström, Commissioner for Trade, as the political agreement between Shinzo ABÉ and Jean-Claude Junker on the signing of the future Economic Partnership Agreement between the European Union and Japan had just been reached, stated that «Nintendo owes its global success to two Europeans: Mario and Luigi!».

This statement is interesting to analyze. On a symbolic level, it basically expresses the crucial idea that the European Union and Japan, lands of culture and civilization thousands of years old in time and space, have come closer together commercially, economically speaking and, in this globalised context, these cultures have now become highly interdependent. What we are talking about here is cultural property, the very strong Japanese predominance of which is to be noted. To put it plainly, if we have Luigi and Mario, Japan has Nintendo...!
However, on closer inspection, we are not entirely sure that this reference to the famous Japanese firm was in the best taste of the Union's partners. The Japanese delegation could also understand in this communication, which was meant to be a form of provocation or a well-understood reminder that Nintendo is also a European legal "saga" for which the Japanese company had to bear the costs.

Indeed, without citing all the judgments in question, it will be recalled that in Cases T-12/03, T-13/03, T-18/03, C-260/09P, the famous Japanese firm was heavily ordered to pay several hundred million euros in fines imposed by the Commission under Article 81(1) EC (101 TFEU) and Article 53(1) of the EEA Agreement. Nintendo or its wholly owned subsidiaries were accused (Case T-12/03) of participating in a complex of agreements and concerted practices in the markets for specialized game consoles and game cartridges compatible with those consoles which had the object and effect of restricting parallel exports of Nintendo game consoles and game cartridges.

In its decision C-335/12 of 24 January 2014, we are not sure that the Japanese company will have fully appreciated the Court's solution, which is no doubt very pragmatic but which refers back to national courts the task of resolving disputes on copyright protection. In this important case, the ECJ initially held that, as a «complex» intellectual creation ${ }^{1}$ peculiar to its author, original computer programs (video games) are protected by copyright under the 2001 Directive $^{2}$. Thus, the TPMs implemented by Nintendo and incorporated in the physical media of video games and in consoles are effective technical measures within the meaning of the Directive. However, secondly, the Court considers that such legal protection against acts not authorized by the copyright holder must necessarily comply with the principle

\footnotetext{
This is the first case, to our knowledge, in which the notion of «complex material» is recognized.

2 Directive 2001/29/EC of the European Parliament and of the Council of 22 May 2001 on the harmonization of certain aspects of copyright and related rights in the information society and Directive 2009/24/EC of the European Parliament and of the Council of 23 April 2009 on the legal protection of computer programs.
} 
of proportionality. TPMs ${ }^{1}$ must therefore not prohibit devices which have a commercial purpose or use other than to facilitate the making of infringements by means of circumvention of technological protection.

On the other hand, in a judgment of 27 September 2017, the Court will have answered a question referred by the Düsseldorf District Court for a preliminary ruling against Nintendo by a German undertaking operating in Germany and France and providing Nintendo with protection for its Community designs of which it was the holder under the 2001 Regulation $^{2}$. The main issue was to determine which court had jurisdiction in this infringement case.

The Economic Partnership Agreement, which will be ratified by Japan on 8 December 2018, entered into force on 1 February 2019. It obviously takes us away both from the Poitiers blockade against Japanese VCRs and television sets in the early 1980s and, hopefully, from those cases that we have just briefly recalled $^{3}$. This agreement is therefore a huge step forward for both partners. On the European side alone at the moment, on a strictly legal level, we feel that the agreement in question is interesting in that it illustrates what are known as new generation agreements.

The EPA is part of a bilateral conventional policy of the Union that has been completely rethought since the mid-2000s. The transition

These are technical protection measures (TPMs) that prevent counterfeit games from being released on any Nintendo system. PC Box, in this case, is a reseller of Nintendo consoles in which various additional software is installed that circumvents and disables the technical protection measures on the consoles.

Council Regulation (EC) No 6/2002 of 12 December 2001. On 22 October 1982, the French Budget Minister, Laurent Fabius, signed a decree forcing importers to stop clearing their video recorders through customs in the ports but in the "center» of France, in Poitiers. A fee similar to that applied to television was subsequently levied on VCRs. These two measures, aimed at limiting the influx of Japanese products and protecting the French consumer electronics industry, have had a huge impact. The press will refer to a new «Battle of Poitiers», in reference to that of 732, when the Franks and Aquitanian had arrested the Saracens from Spain. A debate on French-style "neo-protectionism» will be launched a few months before the left gives up its social policy and two years before the major negotiations on the Single European Act establishing the internal market. from strategy to concrete implementation will take place at the beginning of the decade 2010. The EU-Japan agreement is part of this dynamic. It is useful to come back to this «Global EU» strategy which will have important legal consequences on the content of the agreements concluded by the Union and the exercise of the Union's external competences (A). Still on a legal level, the notion of a new generation agreement is not without real difficulties of identification (B).

\section{A. The Global EU strategy and the EPA}

Political and trade relations between the European Union and Japan took a decisive turn in 2001 at their tenth bilateral Summit in Brussels, where they signed the Action Plan Shaping our common future ${ }^{4}$. Although negotiated in a complex international context ${ }^{5}$, this Action Plan has been the lever for consolidating the economic and strategic partnership between the EU and Japan to the point where, on 25 March 2013, negotiations will be launched - by telephone - on the agreement that holds us back. It has taken the two players just five years to draft the 1864 pages of the treaty ${ }^{6}$ and bring it into force ${ }^{7}$.

The EU-Japan Partnership Agreement is not in itself a surprise. It is in fact part of the very important overhaul of the Union's international action that the Commission presented in 2006 entitled «Global Europe: Competing in the world. A Contribution to the EU's Growth and Jobs Strategy» ${ }^{8}$. The logic of this strategy is twofold: to strengthen the Union's economic power both internally and externally; and to rethink the Union's external action through «new generation» FTAs. Indeed, it is consid-

4 An Action Plan for EU-Japan Cooperation. Available at: https://www.mofa.go.jp/mofaj/area/eu/kodo_k_e. html (accessed: 08.03.2021).

5 The European Union was ready to take action against Japan in the WTO over competition disputes. Monjal P.-Y., The European Union and Japan or double economic openness. General considerations on economic relations between East and West. In: RDUE, 2015, no. 4, pp. 561.

6 The agreement itself is 562 pages long. The annexes are over 1,300 pages long.

7 Mention should also be made of the Strategic Partnership Agreement concluded in parallel (see below).

$8 \operatorname{COM}(2006) 567$ final. 
ered that the above-mentioned expression has been used since 2006; the agreements in question are in fact second generation agreements, as we shall see below.

Point 4-2 of its communication sets out both the Union's strategy for positioning itself in world trade, and in particular with regard to the WTO, and the backbone of the new agreements that the Union is prepared to propose to these partners.

On the first point, the Commission recalls that Europe will not withdraw from multilateralism. It remains committed to the WTO and is working tirelessly to ensure that negotiations resume as soon as the situation in other countries allows. It is the most effective instrument for expanding and steering trade for the benefit of all and the best framework for settling disputes. However, while sparing the WTO, it makes clear that free trade agreements (FTAs) can, if used carefully, promote faster and wider opening and integration, addressing issues that are not yet ripe for multilateral discussion and paving the way for a further level of multilateral liberalization. Many key issues can be addressed in FTAs that are not allowed under WTO rules. In its Concept Paper of 18 September $2018^{1}$ the Commission will be much less conciliatory with the WTO. The reason for this is that the deployment of the Union's new agreements now constitutes a high-quality European standard which the Commission would like to impose from within the WTO in order to reform it $^{2}$.

On the second point, the Commission gives a presentation of the free trade agreements which should constitute the future of the Union's trade relations. The Commission thus recalls that FTAs are not new for Europe: «They play, for example, a key role in the European Neighborhood Policy by strengthening eco-

1 The European Commission presents a comprehensive approach to the modernization of the World Trade Organization, Concept C. Available at: https:// trade.ec.europa.eu/doclib/docs/2018/september/tradoc_157331.pdf (accessed: 08.03.2021).

2 "The European Council of 28-29 June 2018 gave the Commission a mandate to pursue WTO modernization in pursuit of the objectives of making the WTO more relevant and adaptive to a changing world, and strengthening the WTO's effectiveness». nomic and regulatory links with the EU. They are also part of the negotiations for Economic Partnership Agreements with the African, Caribbean and Pacific States as well as in the future Association Agreements with Central America and the Andean Community». This is 2006. But while the bilateral agreements support well the objectives of neighborhood policy and development, the Commission continues, «they serve our main trade interests, including in Asia, less well».

What remains striking in the Commission's analysis are the following three points: Japan is not among the priority target states or partners; new generation FTAs are defined according to economic criteria; new legal considerations.

On the first point, the Union's priorities were Africa, ASEAN, South Korea and Mercosur. India, Russia and the Gulf States were potentially interesting partners.

On the second point, these agreements will be designed on the basis of purely economic criteria: the potential of the markets, its size, its growth, the level of protection measures targeting EU exports such as tariffs and nontariff barriers, the impact of the competitive shock between the Union and the partner...

On the last point, this is obviously the most innovative and «ambitious» aspect on the part of the Commission. In terms of content, it points out, these agreements must be based on new legal bases, extend trade liberalisation including in the field of services and investment, quantitative restrictions on imports and all forms of duties, taxes, charges and restrictions on exports must be eliminated. FTAs should also address non-tariff barriers through regulatory convergence, where possible, and include strong trade facilitation provisions. FTAs should include stronger provisions in favour of intellectual property rights (IPR) and competition, including, for example, provisions on IPR enforcement in line with the relevant IPR Directive.

This retrospective review allows us to have a better understanding of the EPA in the Union's global trade strategy launched and conceived in the mid-2000s, when the Union was only betting on multilateralism. 


\section{B. The legal identification of the EPA}

Legally speaking, under European Union law, there are no so-called "new generation» agreements. This is a purely institutional creation, a practical classification referring to all trade agreements adopted by the European Union after 2006 following the Commission Communication presented earlier. To be even more precise, what are referred to as new generation agreements are in fact second generation agreements, as we shall see. The EU-Japan agreement is, of course, part of this latter classification.

Strictly speaking, the European Union adopts what are known as international agreements under Title $\mathrm{V}$ of the Treaty (Articles 216 et seq.). Doctrine also refers to them as «agreements external to the European Union». These international agreements, again under the Treaty, may be concluded with a State, a group of States (a regional economic integration area such as ASEAN) or an intergovernmental organization. Depending on the degree of economic proximity that the Union wishes to develop, these external agreements will either deal with purely commercial issues or, in addition to commercial issues, will include highly developed political considerations. They are then called association agreements (which very often prepare for EU membership). As can be seen, still in strict law, the category of international agreements that the Union can sign is very limited in formal terms. In material terms, without going into detail, it is the trade agreements responsible for implementing the Union's common commercial policy $^{1}$ that have gradually become the most

This is an exclusive competence of the European Union (Article 3(1)(e) TFEU). The scope of the common commercial policy is broad according to Article 207 TFEU: The common commercial policy shall be based on uniform principles, particularly with regard to changes in tariff rates, the conclusion of tariff and trade agreements relating to trade in goods and services, and the commercial aspects of intellectual property, foreign direct investment, the achievement of uniformity in measures of liberalization, export policy and measures to protect trade such as those to be taken in the event of dumping or subsidies. The common commercial policy shall be conducted in the context of the principles and objectives of the Union's external action. important in terms of economic and political stakes.

In this way, and still in law, the new generation of agreements are bilateral trade and investment agreements that express the Union's objective of acting as a global player on the international stage. Aligned with the values governing its external action, these agreements express the Union's desire to assert itself as a global player in international relations. They include provisions not only on trade in goods, services and the abolition of customs duties, but also on the protection of investments, intellectual property, protection of the environment and social rights, and dispute settlement. The list is not exhaustive. In addition, and most importantly, these agreements also aim to regulate trade «behind the border», i.e. to provide for regulatory harmonization measures based on common international standards. There is also the issue of opening up government procurement markets ${ }^{2}$.

On this basis, the negotiators of bilateral agreements are free to call it whatever they wish. On 29 November 2012, the Council therefore authorised the Commission to open negotiations for a free trade agreement (FTA) with Japan. The FTA with Japan was renamed the «Economic Partnership Agreement» (EPA) following a political agreement in principle reached on 6 July 2017.

In its Opinion 2/15 of 16 May $2017^{3}$, the Court of Justice of the European Union confirmed the exclusive jurisdiction of the European Court of Justice in respect of all aspects covered by the agreement negotiated with Singapore, with the exception of nondirect investment and the settlement of disputes between investors and States in which Member States are involved, which the Court considered to fall within the shared competence of the European Union and the Member States.

2 Koutaro Matsuzawa, Development of the governmental procurement scheme through the Japan-EU economic partnership agreement (JEUEPA).

3 Opinion of the Court (Full Court) of 16 May 2017, Opinion (C-2/15). 
As far as the EU-Japan EPA is concerned, this falls within the exclusive competence of the European Union as its content is in line with the framework set out by the Court in its Opinion 2/15 The legal basis for the EPA is Article 207(1) on the common commercial policy and Article 3(2) TFEU (on the fact that existing common rules contained in secondary legislation are affected by the EU-Japan Treaty). In addition, Articles 91 and 100(2) (transport), 218(6)(a)(v) and 218(7) TFEU (procedure for the conclusion of the agreement). In its simplest terms, the EPA is an international agreement concluded by the European Union under its common commercial and transport policies. However, in terms of its name, which is purely formal, the classification of the EPA remains more subtle. We can make the following remarks.

First of all, the $\mathrm{EPA}^{1}$ is certainly a new generation free trade agreement (FTA) by the official name, but it is again not legal. Already at this stage, complications arise since the EU has long since concluded EPAs with African, Caribbean and Pacific countries $^{2}$. If we retain that the agreement with Japan is an FTA, then it will have to be distinguished from the deep and comprehensive FTAs (CAFTAs) which concern here the Ukraine, and the first generation FTAs (which concern Switzerland, Norway, the Mediterranean countries, Mexico, Chile, Turkey and the Balkans) prior to 2006. Since then, all trade agreements with the European Union are considered as new generation FTAs. This concerns agreements with Vietnam, New Zealand, Australia, Singapore, Mexico, Mercosur, Canada and of course Japan. Eventually, the United Kingdom in its relations with the Union may well fall into this category of partners ${ }^{3}$. In this vast panorama, the EPA with Japan nevertheless has a special significance.

\footnotetext{
1 The media and for convenience we also use the acronym JEFTA (Japan-European Free Trade agreement).

2 Cotonou Agreement of 2000.

3 Report from the European Commission, 31. 10. 2018 $\operatorname{COM}(2018) 728$ final.
}

\section{The mother of Europe is Japanese}

The Declaration of 9 May 1950, a highly symbolic date, is regarded as the founding act of European integration. We need to be more specific. It is the founding act of Community Europe. We should not forget that the Council of Europe was established by the Treaty of London on 5 May 1949 and that its Committee of Ministers decided in 1964 to make 5 May Europe Day under this intergovernmental organization. However, it was at the Milan European Council of 28 and 29 June 1985 that the Heads of State or Government of the Ten decided that, from then on, 9 May of each year would also be Europe Day or Europe Day, but this time, it will have been understood, it will be a Europe of the Community!

European state and people are facing unprecedented economic difficulties linked to VIDOC as well as an equally unprecedented rise in nationalist populism. The 70th anniversary of the Schuman Declaration could have marked the time of European unity, it may well mark the bad times of its division. The year 2020, if we continue with the subject, will remain a very strange year to think about, because as the United Kingdom, whose future relationship with the European Union remains to be defined but could take the form of a new generation FTA, leaves the European Union, we are at the same time celebrating the first anniversary of the trade agreement between the European Union and Japan. So would one FTA replace the other? Would not the internal divisions of the Union be offset by the unity of its conventional trade network? Would not a new generation of players, the Union's trading partners, replace the old generation, the historical European partners?

This analysis would be excessive. However, because there are symbols to be remembered, the very special relationship between Japan and the European Union cannot be ignored. We will allow ourselves an anecdote which arose from an exchange we had with a Japanese diplomat who asked us the following question: "Do you know the Father of Europe and even its Fathers? But do you know the Mother? «. To our silence reflecting our igno- 
rance, the answer was given by our interlocutor: «it is 青山みつ (Mitsuko AOYAMA ${ }^{1}$ ) who was the mother of the famous author of Paneuropa in $1923^{2} \ll$.

Indeed, it is generally considered that if the Fathers of Europe are Jean Monnet and Robert Schuman, it should be remembered that Richard Coudenhove-Kalergi was one of the most important thinkers of European federalism. Let it be said that Europe is Japanese; first from the heart and now from legal reason. On this subject, one will wonder what the stated ambition of the EPA is (A) and whether it does not require consolidation measures (B).

\section{A. The ambition of the EPA}

In its proposal for a Council Decision on the conclusion of the Economic Partnership Agreement between the European Union and Japan of 18 April 2018, the Commission has made clear the ambition followed by the European Union and Japan. The EPA sets out the conditions under which EU economic operators can fully exploit the opportunities offered by the third largest domestic market in the world ${ }^{3}$.

As President Juncker and Prime Minister Abe announced when the negotiations were finalized:

«The EU-Japan EPA is one of the most important and far-reaching economic agreements ever concluded by either the EU or Japan. The EPA will create a large economic area of some 600 million people, representing around $30 \%$ of world GDP, and will also open up huge trade and investment opportunities

Aoyama means blue mountain in Japan.

2 Pan-Europa R. N. Coudenhove-Kalergi, preface by M. Barnier, translation and critical apparatus by V. Klostius, J. Spiri, Paris, Cent Mille Milliards, 2019. $309 \mathrm{p}$.

3 See the European Commission's website for economic figures (Available at: https://ec.europa.eu/trade/policy/ in-focus/eu-japan-economic-partnership-agreement/ index_en.htm). In the case of the EU, the long-term increase in GDP is estimated at $+0.76 \%$ for the most appropriate scenario of full tariff liberalisation and symmetrical reduction of non-tariff measures (NTMs). Bilateral exports can be expected to increase by $34 \%$, while the increase in total world exports would be $4 \%$ for the EU. and help strengthen our economies and societies. The EPA will also enhance economic cooperation between Japan and the EU and strengthen our competitiveness as advanced, yet innovative economies».

Furthermore, the EPA - consisting of twenty-three chapters divided into sections and subsections, 23 articles and 22 annexes is fully consistent with the policies of the European Union as it will never oblige the EU to change its rules, regulations or standards in any area already regulated such as technical rules and product standards, health rules, food safety regulations, health and safety standards, rules on GMOs, environmental protection or consumer protection.

One exception is the bottle size regulated in the 2008 Spirit Drinks Regulations to facilitate Japanese exports of Shochu, which is a traditional alcohol that Japan exports in traditional four-bottle bottles go (合) ou from a sho ( 升 $)^{4}$. In addition, the EPA protects public services and guarantees the right of states to regulate in the public interest.

In economic terms (largo sensu), again in the light of the Commission's analysis, the following is provided for:

- Japan will liberalize $91 \%$ of its imports from the EU upon entry into force of the agreement. At the end of the tariff dismantling period, $99 \%$ of its imports from the EU will be liberalized, while the remaining $1 \%$ will be partially liberalized through quotas and tariff reductions (in agriculture). In terms of tariff lines, Japan fully liberalizes $86 \%$ of its tariff lines upon entry into force, rising to $97 \%$ after 15 years;

- New opportunities for EU bidders to participate in tenders is foreseen. In particular, Japan will give us new access to the 48 subcentral «major cities» with more than 300,000 inhabitants, i.e. about $15 \%$ of the Japanese population, and will agree to abolish, one year after the entry into force of the agreement, the «operational safety clause» for EU companies active in the rail market;

- The removal of technical and regulatory barriers to trade in goods such as duplicative

Sho (升) is equal to $1800 \mathrm{ml}$ and 1 go（合） is equal to $180 \mathrm{ml}$. 
testing, in particular by promoting the use of technical and regulatory standards used in the EU in the areas of motor vehicles, electronics, pharmaceuticals and medical devices, as well as green technologies is enshrined in the Agreement ;

- The EPA contains a chapter on trade in services, investment liberalization and electronic commerce, as well as related schedules of commitments, which go far beyond both parties' WTO commitments;

- un niveau élevé de protection des droits de propriété intellectuelle;

- a high level of protection of EU geographical indications, in accordance with Article 23 of the TRIPS Agreement, for more than 200 EU food and wine and spirits GIs to be protected under the EPA;

- a comprehensive chapter on trade and sustainable development, which aims to ensure that trade supports social development and environmental protection and promotes sustainable forest and fisheries management. This chapter also sets out how civil society will be involved in its implementation and monitoring .

- a new and comprehensive chapter dedicated to SMEs, to ensure that they benefit fully from the opportunities offered by the EPA;

- a comprehensive section on the mutual facilitation of wine exports with the authorization of different oenological practices, including the priority additives of each Party .

At the institutional level, the EPA establishes a Joint Committee to oversee the supervision and implementation of the agreement. This Joint Committee is composed of representatives of the European Union and Japan and will meet once a year or, in case of emergency, at the request of either Party. The Joint Committee will be co-chaired by a representative of Japan at ministerial level and the relevant Member of the European Commission, or their respective delegates. The Joint Committee will be responsible for overseeing the work of all specialized committees and working groups established under the Agreement ${ }^{1}$.

\footnotetext{
Committee on Trade in Goods, Committee on Trade in Services, Liberalization of Investment and Electronic Commerce, Committee on Government Procurement,
}

Ambitions are displayed and implemented. But efforts must be made to consolidate the agreement.

\section{B. The consolidation of the EPA}

In absolute terms, a comparative study of the new generation of EPAs should be carried out in order to measure both their commonalities in the economic areas concerned and, of course, their differences. However, to be completely objective, even if this agreement with Japan is the most important one that the Union has been able to sign in economic terms ( $30 \%$ of world trade) and is very ambitious as we have pointed out, with regard to the agreement with Canada, for example, it remains below that level.

First of all, negotiations continue separately for an Investment Protection Agreement (IPA) with Japan. While the substantive provisions have been agreed, the procedural ones (ICS) are still not accepted by Japan. The last discussions on the IPA took place on 20-22 March 2019 in Tokyo. For the time being, no further discussions are foreseen. The firm commitment of both sides is to complete the investment protection negotiations as soon as possible, in view of their mutual commitment to a stable and secure investment environment in the Union and Japan. Once the parties have reached agreement, investment protection will therefore be the subject of a separate bilateral investment agreement.

Secondly, and this obviously remains an important point, it is indisputable that the EPA cannot in itself provide all the guarantees of satisfaction. The question of the binding nature of the agreement, with regard to some of its provisions, particularly in the social, environmental, competition and sustainable development fields, seems to us to be rather weak in terms of legislation. It is also true that the EPAs have never gone beyond the point

Committee on Trade and Sustainable Development, Committee on Sanitary and Phytosanitary Measures, Committee on Rules of Origin and Customs Matters, Committee on Intellectual Property, Committee on Regulatory Cooperation, Committee on Technical Barriers to Trade and Committee on Cooperation in Agriculture. 
of direct effect. The invocability of the agreement will therefore arise and we know that the Commission has always played strategically on the drafting of the articles of the Union's external agreements in order to neutralize their prevalence over secondary legislation. This is a perfect example of this ${ }^{1}$.

Moreover, contrary to EU law, under Article 16.9 of the EPA, precaution is not defined as a principle but rather as an approach, an orientation, a state of mind $^{2}$. In terms of legislation, legal provisions and constraints on the actors, this name constitutes a clear difference with the precautionary principle as understood in EU law. That said, the parties to the EPA cannot be asked to implement integrated policies as the precautionary principle would imply. While this remains possible in Europe, in the international context the difficulties are much greater to overcome. However, and the step has been taken, the "precautionary approach" expresses an awareness of the limits of scientific knowledge and the need to take measures to prevent a risk.

The consolidation of the EPA is also all the means that the partners will use to adapt their legislation to the EPA. This is particularly the case for intellectual property, as Professor Lenz has shown ${ }^{3}$. Even before the entry into force of the EPA, in the area of intellectual property, Japan made every effort to 'transpose' the rules of the agreement into its law. The same was true of the General Data Protection Regulation of 2016, which required the government and businesses to comply with this regulation. The Commission's adequacy decision of 23 January $2019^{4}$ attests to this major effort to adapt Japan and also to consolidate the $\mathrm{EPA}^{5}$.

1 There are, however, exceptions, ECJ, 8; 06. 1991, Nakajima All Precision Co, ECLI:EU:C:1989:235.

2 A. Donati, The precautionary approach in the economic partnership agreement between EU and japan : a threat to the european precautionary principle?

3 K.-F. Lenz, intellectual property.

4 Commission Implementing Decision (EU) 2019/419 of 23 January 2019 pursuant to Regulation (EU) 2016/679 of the European Parliament and of the Council on the adequate protection of personal data by Japan under the Act on the Protection of Personal Information.

5 Hiroshi Miyashita, EU-Japan Mutual Adequacy Decision.

\section{Conclusion}

Finally, to conclude, it should be recalled that among the EPA consolidation tools is the Strategic Partnership Agreement (SPA), which considerably strengthens the political dimension of relations between the Union and Japan. This practice of backing the economic agreement with a political agreement is not specific to relations with Japan. It is now found in most FTAs. On 26 June 2018, the Council authorized the signing, on behalf of the European Union, of the strategic partnership agreement. The SPA was signed by the EU and Japan on the occasion of the 25th EUJapan summit in Tokyo on 17 July 2018. The EU-Japan Economic Partnership Agreement was also signed in Tokyo on 17 July 2018.

The PSA must comfort the promotion of peace and security, democracy, the rule of law, human rights, fundamental freedoms, regional and international cooperation and UN reform. Furthermore, it must also make it possible to ensure the fight against weapons of mass destruction, serious international crimes, terrorism, cybercrime, and so on ${ }^{6}$. Perhaps the most sensitive issue for Japan is the question of cooperation in the field of international security at a time when the question of the revision of Article 9 of the Japanese Constitution on the prohibition of the use of force arises ${ }^{7}$.

It should be noted that the issue of human rights is not at all the same as it was in the 2000s. The human rights clause is now seen in a positive, cooperative rather than punitive way. In legal terms, this translates into the signing of a SPA which is backed by the EAP. The separation of economic and political issues is clearly separated. Moreover, one wonders whether the «moralization» of EPAs does not now include the introduction of the essential elements of sustainable development and

6 DÉCISION (UE) 2018/1197 DU CONSEIL du 26 juin 2018. Available at: http://publications. europa.eu/resource/cellar/c212d326-a761-11e899ee-01aa75ed71a1.0009.03/DOC_1 (accessed: 08.031.2021)/

7 Fumi Yoshimoto, EU-Japan cooperation in the security field from the perspective of japan's legal framework. 
the precautionary principle. On this point, the EPA with Japan is a good example.

This agreement, which now binds us together, is absolutely unique in itself, both in terms of its scope and the players involved. But perhaps most exciting is that the bridge Victor Hugo dreamed of building between the Union and the United States will be the bridge between Europe and Japan. A bridge like the one in Edo, where merchants, artists, poets, lawyers, students, professors... will cross with happiness.

Статья поступила в редакцию 26.11.2020.

\section{INFORMATION ABOUT THE AUTHOR}

Pierre-Yves Monjal - Prof. in Public Law, University of Tours, Jean-Monnet Chair, Director of the NihonEuropA programme, Vice-Director of the Institut de Recherche Juridique Interdisciplinaire de Tours;

e-mail: pymonjal@mac.com

\section{ИНФОРМАЦИЯ ОБ АВТОРЕ}

Монжал Пьер-Ив - профессор публичного права Турского университета, директор программы NihonEuropA, заместитель директора Междисциплинарного института правовых исследований (г. Тур)

e-mail:pymonjal@mac.com

\section{FOR CITATION}

Monjal P.-Y. Topical Issues of Legal Regulation of International Agreements on the Example of East and West (Theoretical and Legal Research). In: Bulletin of Moscow Region State University. Series: Jurisprudence, 2021, no. 1, pp. 15-24.

DOI: $10.18384 / 2310-6794-2021-1-15-24$

\section{ПРАВИЛЬНАЯ ССЫЛКА НА СТАТЬЮ}

Монжал П.-И. Актуальные вопросы правового регулирования международных соглашений на примере Востока и Запада (теоретико-правовое исследование) // Вестник Московского государственного областного университета. Серия: Юриспруденция. 2021. № 1. С. 15-24.

DOI: $10.18384 / 2310-6794-2021-1-15-24$ 